\title{
Meningkatkan Kemampuan Metafora menggunakan Strategi React Berbantuan Bahan Ajar Aljabar
}

\author{
Rani Sugiarni', Sendi Ramdhani ${ }^{2}$ \\ 1,2 Pendidikan Matematika, Fakultas Keguruan dan Ilmu Pendidikan, Univrsitas \\ Suryakancana, Cianjur, Indonesia \\ E-mail: rani@unsur.ac.id
}

\begin{abstract}
ABSTRAK
Abstrak. Kemampuan matematika siswa masih rendah, khususnya kemampuan metafora. Penelitian ini bertujuan untuk mengetahui peningkatan kemampuan metafora matematis siswa dengan strategi $R E A C T$ berbantuan Bahan Ajar Aljabar. Metode penelitian menggunakan Penelitian Tindakan Kelas yang dilaksanakan dalam 2 siklus tindakan. Populasi dalam penelitian ini adalah siswa-siswi kelas VII SMP AlMadina tahun ajaran 2017-2018, sampel pada penelitian ini sebanyak 22 orang. Instrumen yang digunakan adalah soal tes kemampuan metafora tiap siklus, lembar observasi guru dan sisiwa dalam pembelajaran. Hasil penelitian menunjukan bahwa dengan menerapkan pembelajaran dengan Strategi REACT berbantuan bahan ajar Aljabar dapat meningkatkan kemampuan metafora para siswa di SMP Al-Madina. Hal ini ditunjukan dengan hasil tes kemampuan metafora setiap siklusnya. Pada tindakan siklus I daya serap klasikal siswa menacapai $59 \%$, dan tindakan siklus II hampir 77 \% daya serap klasikal mengalami peningkatan. Selain itu aktivitas guru dan siswa pada setiap siklus baik. Berdasarkan hasil penelitian tersebut disimpulkan bahwa pembelajaran dengan stategi REACT dapat meningkatkan kemampuan metafora.

Kata kunci: REACT, Kemampuan Metafora, PTK
\end{abstract}

\begin{abstract}
Abstract. The mathematical ability of students is still low, especially the ability of metaphor. This study aims to determine the improvement of students' mathematical metaphorical abilities with the strategy of REACT aided Instructional Materials Algebra. The research method uses Classroom Action Research which is implemented in 2 action cycles. Population in this research is student of class VII of Al Madina Junior High School year 2017-2018, sample in this research counted 22 people. The instrument used is a matter of metaphor ability test each cycle, teacher observation sheet and side in learning. The results showed that by applying the learning with REACT Strategy assisted Algebra learning materials can improve the metaphor ability of the students at Al Madina Junior High School. This is indicated by the metaphor capability test results of each cycle. In the cycle I action the classical absorption of students reaches 59\%, and the second cycle action almost 77\% of the classical absorption is increased. In addition, the activities of teachers and students in each cycle well. Based on the results of this study concluded that learning with REACT strategy can improve the ability of metaphor.
\end{abstract}

Keywords: REACT, Metaphorical Ability, PTK 


\section{PENDAHULUAN}

Pendidikan mempunyai peranan yang sangat penting dalam membangun bangsa yang maju yang mampu bersaing dengan negara lainnya. Peranan pendidikan sekarang ini semakin menantang dengan semakin canggihnya teknologi dan luasnya ilmu pengetahuan yang tersebar dengan mudah. Namun dengan mudahnya ilmu pengetahuan yang mudah dapat acap sering teerjadi kenakalan remaja semakin merajalela.

Kenakalan remaja sering kali ada terutama untuk jenjang pendidikan mulai dari sekolah dasar, sekolah menengah pertama bahkan sekolah menengah atas. Terlibih biasanya yang sering muncul kenakalan pada remaja acapkali disebabkan oleh krisis moral. Krisis moral para remaja pada era globalisasi ini seiring dengan perkembangan zaman yang semakin maju telah meluasnya ilmu peengetauan. Banyak beritaberita ditelevisi ataupun dari surat kabar yang meberikan berita tentang krisis moral contohnya berita terjadinya sejumlah siswa masih saja berani adu jotos bahkan saling melukai menggunakan senjata tajam. Tauran ini terjadi pada remaja SMP di Cianjur 23/o3/2017 (pojokpajar.com, 2017). Salah satu contoh permasalahan tersebut diakibatkan krisis moral yang melanda siswa-siswi.

Krisis moral akan berdampak pada nilai-nilai khususnya matematika rendah. Sedangkan peranan matematika sangat penting untuk melatih mengasah pemecahan masalah khususnya matematika umumnya tantangan permasalahan kehidupannya. Hal ini terlihat hasil observasi dan wawancara antara guru dan siswa sebagian besar $65 \%$ dari keluarga yang kurang mampu secara ekonomi yang mendapatkan bantuan dari pemerintah dan mempunyai latar belakang keluarga yang tidak baik seperti korban perceraian atau ditinggal orang tua ke luar negeri (TKW) dan titipkan kepada neneknya dan kurang mendapat perhatian sehingga rawan krisis moral yang dihadapi anak pada zaman yang serba berkembang ini.

Selain itu rendahnya materi aljabar dilihat dari rata-rata nilai ulangan harian di SMP AlMadina pada materi Aljabar adalah 65 dengan nilai kritia ketuntasan minimal 71, siswa-siswi yang tergolong tuntas dilihat dari KKM hanya berkisar 5 orang dari 42 orang siswa disetiap kelasnya. Kesulitan siswa dalam aljabar kebanyakan karena materi tersebut bersifat abstrak mengakibatkan siswa kurang memahami. Faktor lain yang mempengaruhi hasil belajar diantaranya kemampuan awal siswa, tingkat kecerdasan dan motivasi belajar (lestari, 2017). Tujuan pembelajaran akan tercapai apabila perencanaan dan metode yang digunakan dapat mempengaruhi potensi dan kemampuan yang dimiliki peserta didik dan keberhasilan tersebut akan tercapai apabila peserta didik dilibatkan dalam proses berpikirnya(Sugilar, 2013).

Menurut Lasmanah (2016) usia siswa untuk jenjang SMP adalah 13-15 perkembangan kognitif siswa berada pada tahap operasi konkrit, hal ini sejalan dengan hasil penelitian Suherman (1987)menyatakan, “ ... pada siswa yang berusia $9-14$ tahun mayoritas berada pada tahapan operasional konkrit (80,73 \%), sebagian kecil sudah mencapai operasional formal $(6,52 \%)$ dan ada juga yang masih berada pada tahap pra operasional (12,75\%) ... (dalam Lasmanah, 2016)". Ditinjau dari permasalahan tersebut ternyata siswa masih rendah dalam kemampuan metafora dalam materi aljabar.

Khairiyah, R. (2018) menyatakan kemampuan metafora adalah proses berpikir untuk memahami konsep abstrak menjadi hal yang konkrit dengan menganalogikan sesuatu yang abstrak dengan sesuatu konkrit. Kemampuan metafora ini sangat penting dimiliki oleh siswa terutama dalam materi aljabar. Selain itu Alhaddad (2012) mengungkapkan bahwa metafora dipandang sebagai strategi dalam membantu siswa memahami materi matematika. Hal lain metafora diartikan sebagai berpikir metaora atau metaphorical thinking (. siswa berperan secara tidak langsung mampu merangsang pemikirannya dalam menghubungkan antara konsep dan fenomena nyata disekitar.

Menurut Hendriana (2017) menyatakan pengembangan siswa dalam kemampuan bertanyya dan berpikir metafora adalah: (1) siswa dapat menghubungkan masalah 

MeningkatkanKemampuan Metafora Menggunakan Strategi React Berbantuan Bahan Ajar Aljabar

pernyataan yang diberikan menjadi pertanyaan yang diajukan untuk menggali informasi yang lebih dalam, (2) siswa dapat menemukan yang baru konsep yang belum dikenal seperti dugaan yang diharapkan menjadi dasar dari pertanyaan mereka, (3) para siswa mampu menciptakan ide-ide kreatif yang berasal dari masalah yang dihadapi, dan (4) siswa dapat menerapkan hasil pemikiran mereka dalam bentuk pertanyaan dari masalah yang diberikan pernyataan.

Metafora kita kenal dengan gaya bahasa yang membedakan satu dengan yang lainnya. Dalam matematika metafora dikaitkan dengan berpikir. Dimana bisa mengaitkan konsep matematika dengan dunia nyata. Sejalan dengan Karunia dan Ridwan berpikir metafora merupakan kemampuan memodelkan satu situasi matematis yang dimaknai dari sudut pandang sematik menggunakan metafora. Adapun indikator berpikir metafora yaitu mengidentifikasi konsep utama, menghubungkan konsep matematika dengan kosep kehidupan nyata dan mengilustrasikan gagasan/ide matematisnya ke dalam metafotra (Karunia dan Ridwan, 2015).

“...that empowering students to be aware of their own learning processes, in the context of self-regulated learning, can contribute to learning to learn together". (Andreas Harrer, 2013. )metafora diartikan memberdayakan siswa untuk menyadari pembelajaran mereka sendiri yang dalam konteks pembelajaran mandiri, dapat berkontribusi pada belajar.

Dari beberapa pendapat diatas kemampuan metafora yang dimaksudkan adalah dimana siswa mampu memodelkan permasalahan matematika dalam kehidupan nyata dengan mandiri sesuai dengan pemahaman siswa dalam menanggapi permasalahan tersebut.

Menghadapi tantangan permasalahan krisis moral peranan pendidikan khususnya guru dibutuhkan untuk meminimalisir krisis moral siswa-siswi dengan sebuah strategi pembelajaran yang menumbuhkan kemampuan metafora, motivasi dan kepercayaan diri untuk meminimalisis krisis moral tersebut.

Salah satu model pembelajaran yang dapat menjadi solusi adalah menggunakan stategi
REACT (relating, experiencing, applying, cooperating, transferring) berbantuan bahan ajar. Strategi ini merupakan strategi pembelajaran dengan pendekatan kontekstual.

Menurut Arifin, dkk stategi REACT dapat meningkatkan kemampuan matematis siswa SMP karena pertama proses relating siswa diharapkan mampu mengidentifikasi suatu permasalahan dan memberikan penjelasan yang sederhana, dimana penjelasan itu akan mendorong siswa mengeluarkan ide-idenya. Kedua ide-ide tersebut dapat dimanfaatkan untuk membangun keterampilan dasar siswa saat siswa melakukan experiencing .ketiga dan keempat supaya siswa mampu membuat kesimpulan yang baik, siswa bisa melakukannya dalam kelompok denga berdiskusi,diharapkan siswabisa memberikan penjelasan yang lebih lanjut dan mengatur strategi serta taktik dalam mengaplikasikan konsep yang sedang dipelajari dalam apllying dan transferring.

Sejalan dengan penelitian El Husna, F. (2014), Herlina, S., Turmudi, M., \& Dahlan, J. A. (2012), Siahaan, F. B. (2012) stategi REACT dapat meningkatkan kemampuan dalam belajar matematika.

Diharapkan dengan stategi REACT dapat meningkatkan kemampuan metafora dan kepercayaan diri siswa yang dibantu dengan bahan ajar berupa buku yang didalamnya terdapat kata-kata positif yang membantu meningkatkan kepercayaan diri siswa dalam mengahadapi permasalahan dan tantangan krisis moral.

\section{METODE PENELITIAN}

Metode yang digunakan dalam penelitian adalah Penelitian Tindakan Kelas (Classroom Action Research) yang merupakan bentuk kajian yang bersifat refleksi oleh pelaku tindakan yang ditujukan untuk meningkatkan kemampuan metafora siswa, secara sengaja dilakukan selama pembelajaran.

Model penelitian yang digunakan pada penelitian ini berbentuk siklus-siklus yang merupakan metode yang dikembangkan oleh Kemmis dan Mc. Taggart, meliputi perencanaan (planing), aksi atau tindakan (acting), 
observasi (observing), dan refleksi (reflecting) (Aqib, 2006). Penelitian ini terdiri dari dua siklus dan dua kali tes yang bertujuan untuk mengetahui perkembangan kemampuan metafora siswa menggunakan stategi REACT berbantuan bahan ajar Aljabar. Penelitian tindakan kelas ini di SMP Al-Madina dengan subjek penelitian tindakan kelas yang akan dilakukan yaitu pada siswa kelas VII tahun ajaran 2017-2018 dengan materi Aljabar.

Teknik pengumpulan data dalam penelitian ini dilakukan dengan cara menentukan terlebih dahulu sumber data, jenis data, instrumen yang digunakan dan teknik pengumpulannya.

\section{HASIL DAN PEMBAHASAN}

Hasil analisis penilaian hasil tes kemampuan metafora siswa pada tiap siklus sebagai berikut:

Tabel 1. Data Hasil Tes Siklus

\begin{tabular}{l|c|c}
\hline \multicolumn{1}{c|}{ Data } & Siklus I & Siklus II \\
\hline Siswa Tuntas & 13 & $\mathbf{1 7}$ \\
\hline Nilai Terendah & 1 & $\mathbf{5 6}$ \\
\hline Nilai Tertinggi & 89 & $\mathbf{1 0 0}$ \\
\hline Nilai Rata-rata & 69,43 & $\mathbf{8 4 , 4 5}$ \\
\hline $\begin{array}{l}\text { Daya Serap } \\
\text { Klasikal }\end{array}$ & $\mathbf{5 9 \%}$ & $\mathbf{8 4 \%}$ \\
\hline
\end{tabular}

Hasil analisis dari Tabel 1 terlihat bahwa dari siklus I sampai siklus II nilai siswa mengalami peningkatan. Hal ni terlihat dari meningkatnya ketuntasan, dan Daya Serap Klasikal (DSK), kemudian didukung dengan sikap siswa yang antusias dalam pembelajaran. Nilai kemampuan metafora tertinggi mencapai nilai sempurna dan untuk nilai terendah mengalami peningkatan menuju lebih baik untuk setiap siklusnya. Dengan demikian dapat disimpulkan bahwa penerapan pembelajaran menggunkan strategi REACT berbantuan bahan ajar aljabar dapat meningkatka kemampuan metafora siswa pada materi aljabar.

\section{Aktivitas Siswa dan Guru}

Selain melihat peningkatan kemampuan metafora siswa, peneliti juga melihat bagaimana suasana pembelajaranmenggunakan strategi REACTberbantun bahan ajar berlangsung. Hal ini dilihat dari hasil aktivitas siswa dan guru pada setiap siklusnya yang mengalami peningkatan dan termasuk pada kategori baik pada setiap pertemuan. Aktivitas guru menunjukan hal yang baik dengan mengkondisikan siswa begitupun siswa berperan aktif selama proses pembelajaran berlangsung.

Dari hasil observasi siswa pada siklus I, siswa yang tuntas sebanyak 13 orang dari 23 orang. Peneliti berusaha untuk meningkatkan suasana belajar siswa agar menyenangkan, percaya diri dan lebih bisa merangsang kemampuan metafora siswa pada pertemuan selanjutnya. Adanya peningkatan pada siklus II dengan jumlah siswa yang tuntas sebanyak 17 orang merupakan peningkatan yang baik dikarenakan siswa telah terbiasa pada pembelajaran yang diterapkan di kelas. Terlihat pada saat pembelajaran berlangsung siswa antusias dalam membaca bahan ajar, bertanya, menjawab pertanyaan-peertanyaan pada bahan ajar dan mempresentasikan hasil jawabannya di depan kelas.

\section{Respon Siswa Terhadap Pembelajaran Matematika dengan Strategi REACT berbantuan bahan ajar}

Untuk mengetahui respon siswa terhadap pembelajaran dengan menggunakan strategi REACTberbantuanbahan ajar peneliti menggunakan angket sebagai instrumen. Angket tersebut terdiri dari 30 pertanyaan yang bersifat positif dan negatif. Pada umumnya, siswa bersikap positif terhadap .......yaitu dengan nilai rata-rata sebesar 3,55. Selain dihitung secara keseluruhan, skala sikap siswa juga dianalisis berdasarkan tujuh indikator. Indikato-indikator tersebut dapat dilihat dari tabel berikut:

Tabel 2. Data Skala Sikap

\begin{tabular}{lcc}
\hline Indikator & $\begin{array}{c}\text { Banyaknya } \\
\text { pernyataan }\end{array}$ & $\begin{array}{c}\text { Modus/ } \\
\text { Median }\end{array}$ \\
\hline Terhadap Materi Aljabar & 4 & 4 \\
Peranan Guru & 4 & 4 \\
Strategi REACT & 9 & 4 \\
Interaksi Teman & 4 & 4 \\
Kemampuan Metafora & 4 & 4 \\
Bahana Ajar & 3 & 4 \\
\hline
\end{tabular}


MeningkatkanKemampuan Metafora Menggunakan Strategi React Berbantuan Bahan Ajar Aljabar

Dari tabel 2. diperoleh data skala sikap siswa terhadap ketujuh indikator, yaitu terhadap materi aljabar, peranan guru, pembelajaran dengan strategi REACT, interaksi dengan sesama teman, kemampuan metafora dan bahan ajar aljabar. Sikap siswa terhadap materi aljabar mendapatkan nilai rata-rata modus sebesar 4 dari 4 pernyataan, maka sikap siswa bersifat positif. Sikap siswa terhadap peranan guru mendapatkan nilai modus sebesar 4 dari 4 pernyataan, maka sikap siswa bersifat positif. Selanjutnya dilihat dari bahan ajar Aljabar yang digunakan mendapatkan nilai rata-rata modus sebesar 4 dari 2 pernyataan, maka sikap siswa bersifat positif. Begitupun terhadap strategi REACT, interaksi teman, kemampuan metafora dan bahan ajar yang memiliki nilai rata-rata 4 menyatakan bahwa sikap siswa bersifat positif. Dengan demikian dapat diperoleh kesimpulan bahwa sikap siswa terhadap strategi REACT berbantuan bahan ajar Aljabar berkesan positif.

\section{KESIMPULAN}

Berdasarkan hasil penelitian dan anlisis terhadap pembelajaran matematika menggunakan strategi REACT berbantuan Bahan ajar Aljabar untuk meningkatkan kemampuan metafora siswa terhadap materi Aljabar di SMP Al-Madina kelas VII dengan materi Aljabar pada siswa rawan krisis moral, maka kesimpulan yang diperoleh adalah: pertama, pembelajaran matematika strategi REACT berbantuan bahan ajar Aljabar dapat meningkatkan kemampuan metafora siswa. Kedua, aktivitas siswa dan guru terhadap strategi REACT berbantuan bahan ajar Aljabar baik. Dan ketiga, respon siswa dalam strategi REACT berbantuan bahan ajar Aljabar umumnya menghasilkan kesan yang positif.

\section{UCAPAN TERIMA KASIH}

Kami mengucapan terimakasih kepada semua pihak yang ikut membantu dalam pelaksanaan penelitian dan DDRPMRistekdikti yang telah memberikan dukungan materi sehingga bisa terlaksana penelitian ini.

\section{DAFTAR PUSTAKA}

[1] Alhaddad, I. 2012. Sejauh Mana Guru Menggunakan Metafora Dalam Kepeduliannya untuk meningkatkan Kemampuan Matematika Siswa. Infinity Journal, 1(2), 159-168. El Husna, F. (2014). Penerapan Strategi REACT Dalam Meningkatkan Kemampuan Pemahaman Konsep Matematika Siswa Kelas X SMAN 1 Batang Anai. Jurnal Pendidikan Matematika, 3(1).

[2] Arifin, A.T, Kartono, Sutarto, H. 2014. Keefektifan Strategi Pembelajaran React Pada Kemampuan Siswa Kelas VII Aspek Komunikasi Matematis. Jurnal Kreano, Volume 5 Nomor 1, Halaman $91-98$. Semarang : FMIPA UNNES.

[3] Erawati, Ria. 2016. Penerapan Strategi Pembelajaran Aktif Tipe Active Knowledge Sharing untuk Meningkatkan Aktivitas dan Hasil Belajar Siswa pada Mata Pelajaran IPS kelas IV SDN 3 Metro Barat. SkripsiAndreas.

[4] Hendriana, H. 2017. Senior High School Teachers'mathematical Questioning Ability And Metaphorical Thinking Learning. Infinity Journal, 6(1), 5158.

[5] Herlina, S., Turmudi, M., \& Dahlan, J. A. 2012. Efektivitas Strategi React Dalam Upaya Peningkatan Kemampuan Komunikasi Matematis Siswa Sekolah Menengah Pertama. Jurnal Pengajaran MIPA, 17(1), 1-7.

[6] Harrer, K. P. ,. R. D. G. ,. A. R. A., 2013. . Research On Collaborative Planning And Reflection -. Springer-Verlag Berlin Heidelberg, Volume EC-TEL 2013, LNCS 8095, Pp. Pp. 139-150. 
Rani Sugiarni dan Sendi Ramdhani

[7] Khairiyah, R. 2018. Pengaruh pembelajaran matematika berbasis drama terhadap kemampuan berpikir metafora (Bachelor's thesis, UIN Syarif Hidayatullah Jakarta: Fakultas Ilmu Tarbiyah dan Keguruan, 2018).

[8] Lasmanah, A. 2017. Peningkatan Hasil Belajar Matematika Siswa Melalui Model Kooperatif Teknik Think Pair Share (Tps)(Penelitian Tindakan Kelas Terhadap Siswa Kelas Vii-A Smpn Sukasari Sumedang”. Jurnal Analisa, 2(3), 18-25.

[9] Lestari, K.E. Dan Yudhanegara, M.R. 2015. Penelitian Pendidikan Matematika. Bandung: PT. Refika Aditama.

[10] Lestari, w. 2017. Pengaruh Kemampuan Awal Matematika dan Motivasi Belajar Terhadap Hasil Belajar Matematika. Tersedia [online] http://journal.uinsgd.ac.id/index.p hp/analisa/article/view/1499/1053

[11] Pojokpajar.Com, 2017. Buktikan Sanksi Tegas Tawuran Pelajar Di Cianjur. [Online] Available At: Http://Jabar.Pojoksatu.Id/Uncateg orized/2017/03/25/Buktikan-

Sanksi-Tegas-Tawuran-Pelajar-DiCianjur/ [Diakses 31 Mei 2017].

[12] Siahaan, F. B. (2012). Pengaruh Strategi React Dan Sikap Siswa Terhadap Matematika Dalam Peningkatan Kemampuan Koneksi Matematika Siswa Sma. Jurnal Paradikma, 5(02), 129-137.

[13] Sugilar, H. 2013. Meningkatkan Kemampuan Berpikir Kreatif Dan Disposisi Matematik SiswaMadrasah Tsanawiyah Melalui Pembelajaran Generatif. [online] Jurnal Ilmiah Program Studi Matematika STKIP Siliwangi 